بررسى اثر كاربرد نفت سفيد بر جذب عناصر سنگين در برخى از سبزىها در استان خوزستان

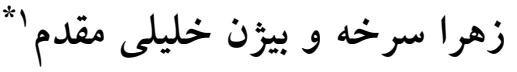

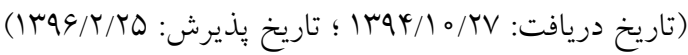

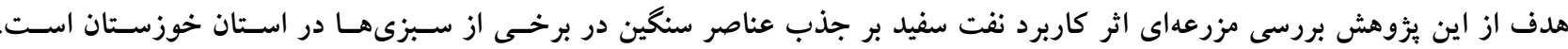

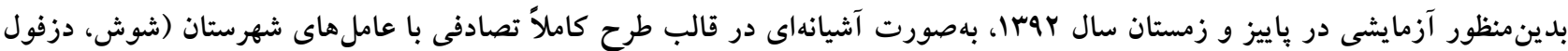

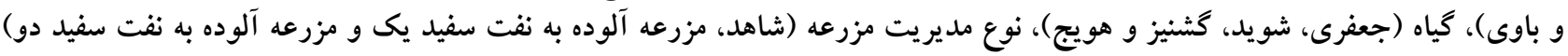

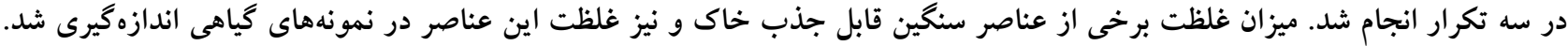

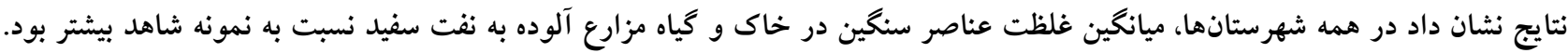

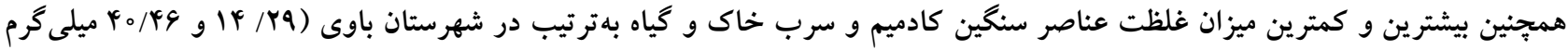

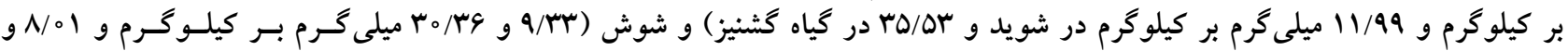

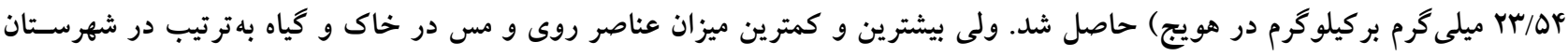

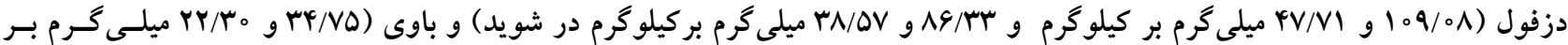

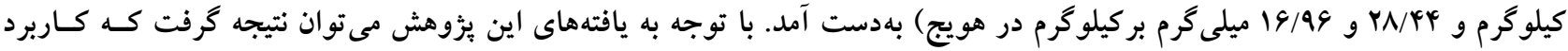

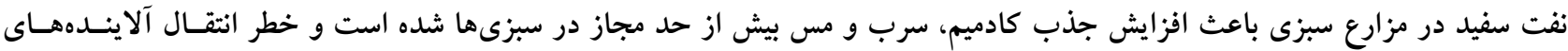

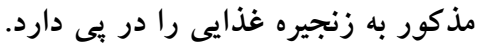

وازههاى كليدى: نفت سفيد، فلزات سنخين، علف هرز، سبزىها، خوزستان 
حضــور قـارج ميكــوريزا ميـزان غلظـت عناصـر ســخين در

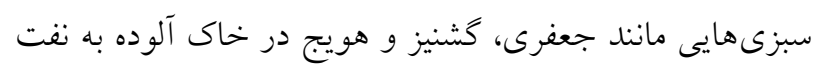

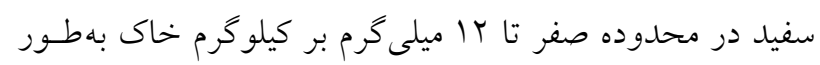

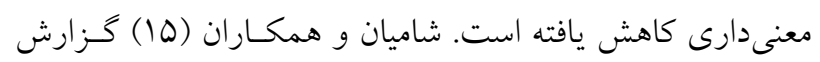

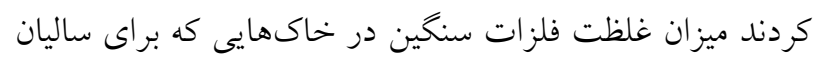

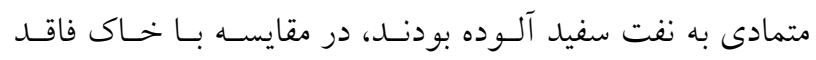

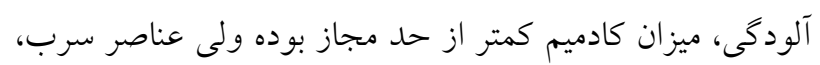

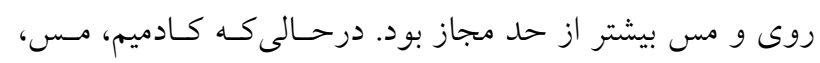
روى و سرب در خاك غير آلوده در حد مجاز بود.

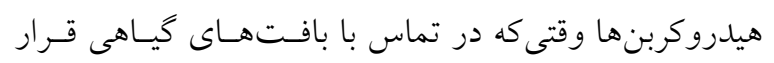

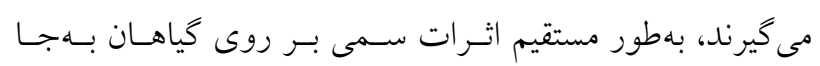

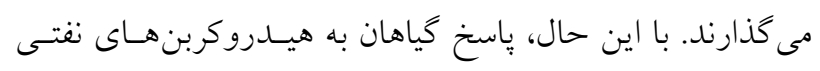
متفاوت است. برخى از گياهـان در مقابـل ايسن آلـودخى مقــاوم

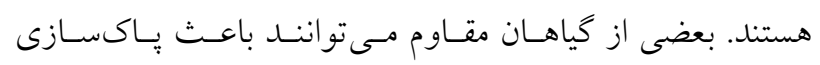

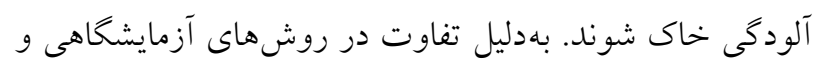

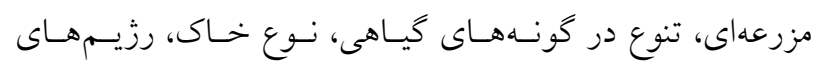

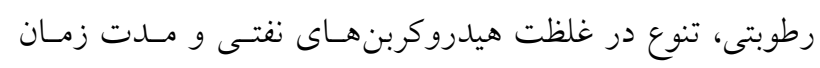

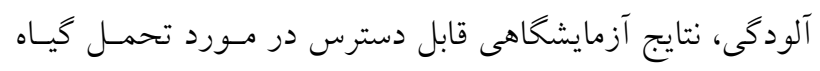
به آلودكى خاك بوسيله نفت سفيد اندى است. عـلاوهبــ ايسن،

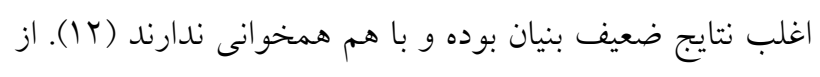

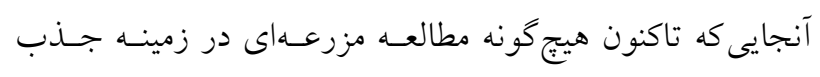

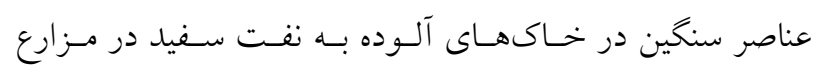

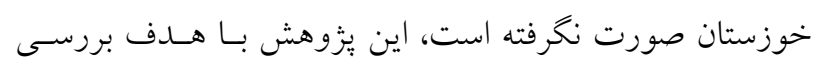

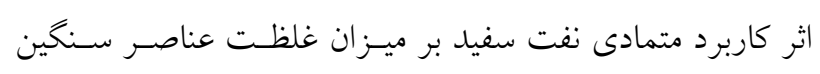
قابل جذب خاك و كياه در مزارع سبزى استان خوزستان انجـام

\section{مواد و روش بررسى}

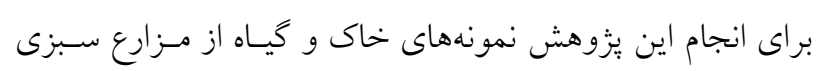

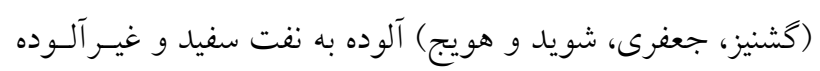

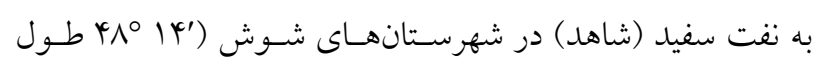

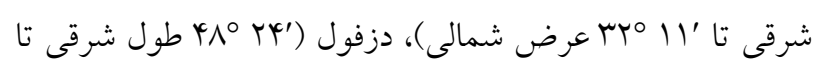

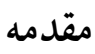

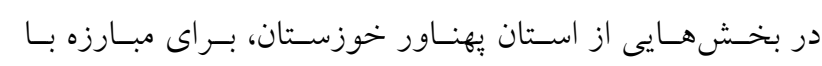

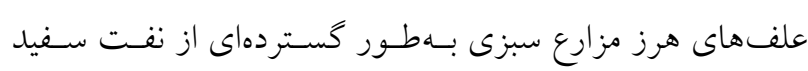

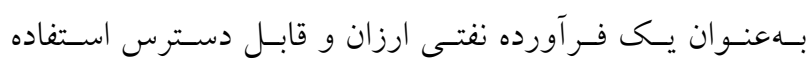

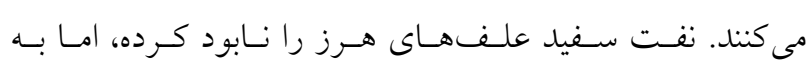

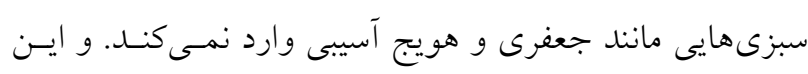

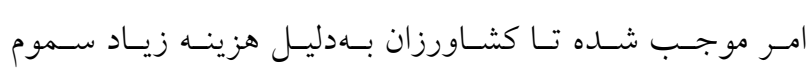

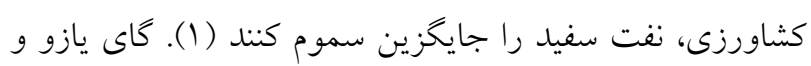

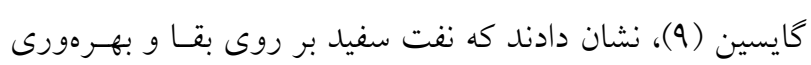

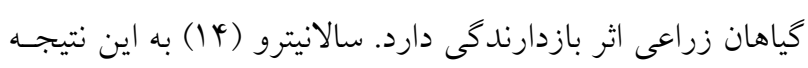

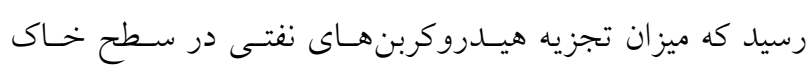

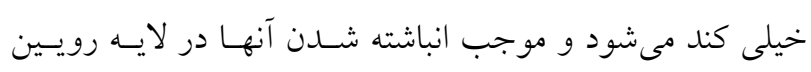

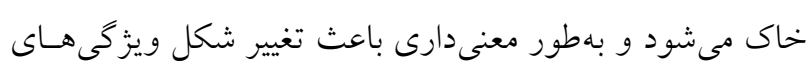

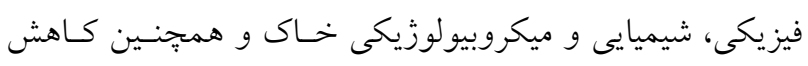

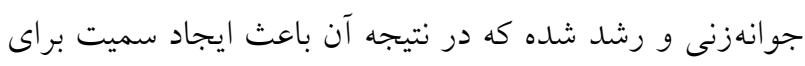

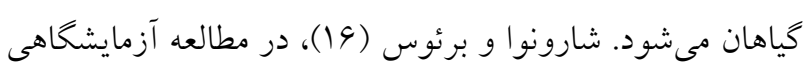

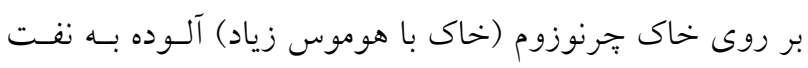

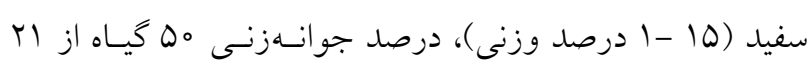

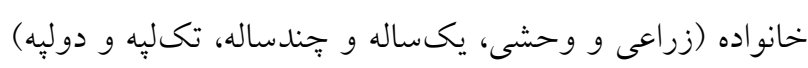

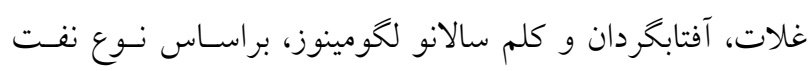

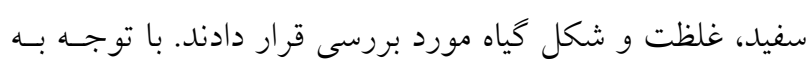

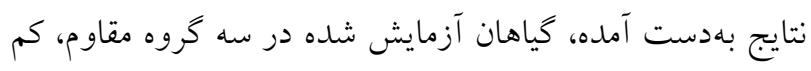

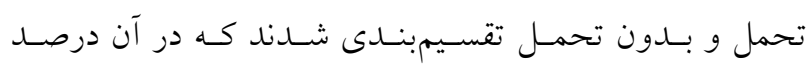

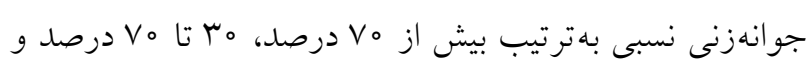

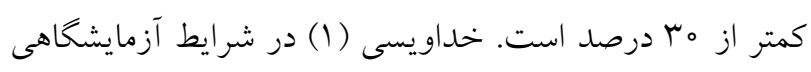

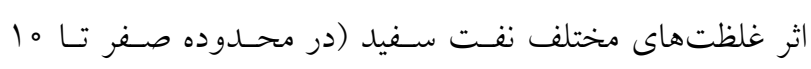

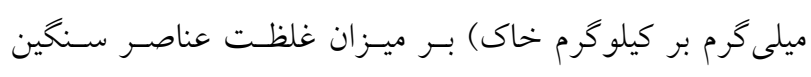
(سرب، كادميم، روى و مس) در خاك و گياه (جعفرى، گشنـيز

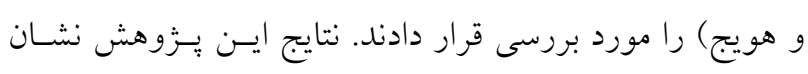

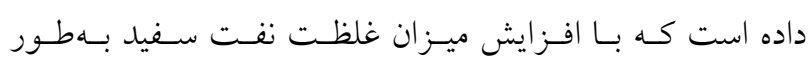

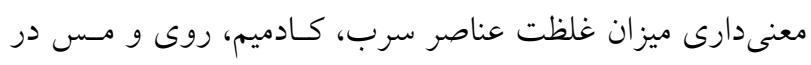

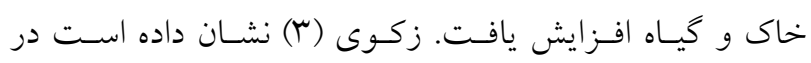


جدول ا. برخى خصوصيات اوليه خاك مزارع شهرستانهاى شوش، دزفول و باوى

\begin{tabular}{|c|c|c|c|c|c|c|c|c|}
\hline خنتى شونده (آهك) & جِاسيم قابل & فسفر قابل & نيتروزن & $\mathrm{pH}$ & كربن آلى & $\begin{array}{c}\text { شورىى } \\
\left(\mathrm{dS} \mathrm{m}{ }^{-1}\right.\end{array}$ & بافت & شهرستان \\
\hline (درصد) & \multicolumn{2}{|c|}{$(\mathrm{ppm})$} & & & & & & \\
\hline$\varphi 1 / \mu$ & Trt & $V / T$ & $1 / 0 \mu$ & $V / T$ & 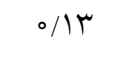 & $r / \Delta$ & لوم رسى شنى & شوش \\
\hline$K Y / \Lambda$ & rQA & $\mid r / 1$ & T/OT & $V / T$ & $\circ / V G$ & $T / V$ & لوم رسى شنى & دزفول \\
\hline$\varphi Q / 1$ & TIY & $9 / 4$ & $\circ / \circ \mathrm{V}$ & $V / 9$ & $0 / 09$ & $r / 9$ & رسى شنى & باوى \\
\hline
\end{tabular}

شدند. نمونههاى گياه در آزمايشخاه بهوسيله آب مقطر شسته شده و به دو قسمت ريشه و بخش هوايى تقسيم شدند. سبس نمونهها

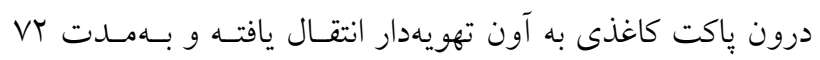

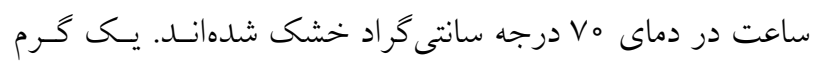
مـاده خشـى گيـاهى در كـوره الكتريكسى در دمـاى مها درجسهـ سانتى گراد بهمدت جهار ساعت بهصورت خاكسـتر در آورده شـد و سبس خاكستر حاصل در اسيد كلريدريك حـل شـــ و يسـ از صاف نمودن با كاغذ صافى، حجم نهايى محلول به مه ميلىمتـر رسانيده شد. غلظت كـادميم، سـرب، روى و مسس بـا اسـفاده از

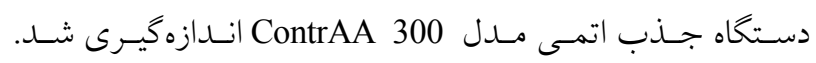
دادههاى جمـع آورى شـده بـا اسـتفاده از نـرم افزارهـاى SAS و MSTATC تحليل شدند.

\section{نتايج و بحث}

تجزيه واريانس غلظت عناصر سنخين (كـادميم، سـرب، روى و

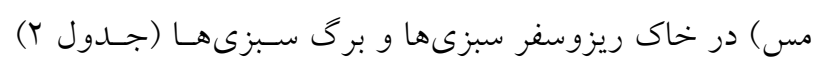

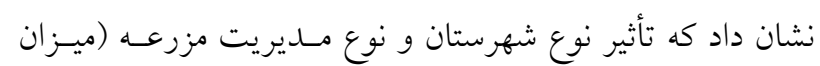

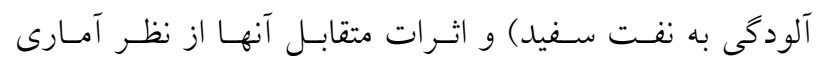

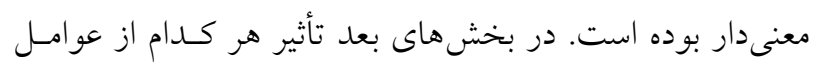
مذكور مورد بحث قرار مى گيرد.

تأثير ميزان نفت سفيد بر مقـدار غلظــت عناصـر ســخين خــاك ريزوسفر سبزىها ميـانخين غلظـت كـادميم، سـرب، روى و مس در در نمونسهــاى

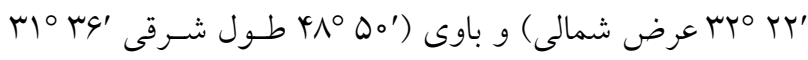

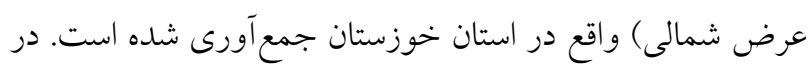

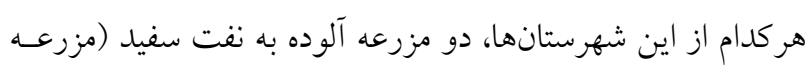

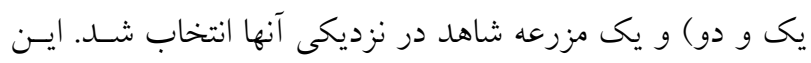

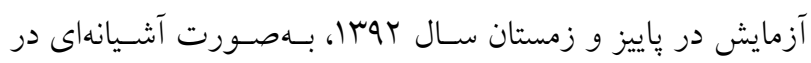

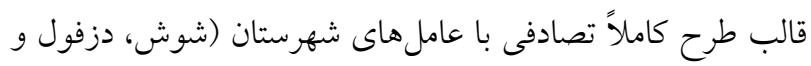

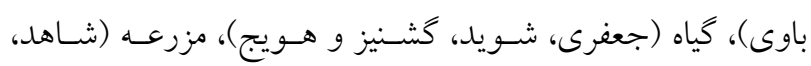

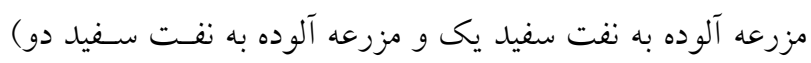

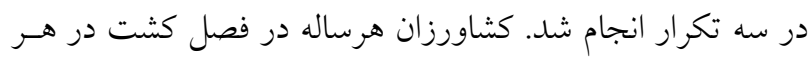

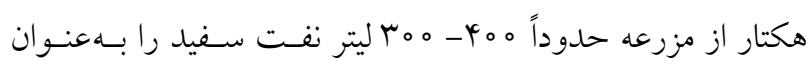

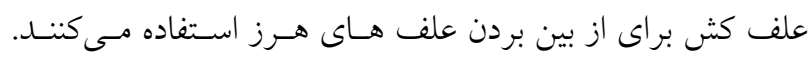

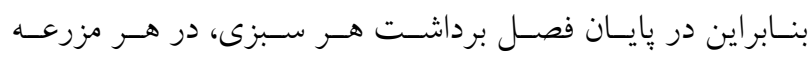

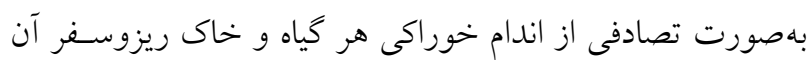

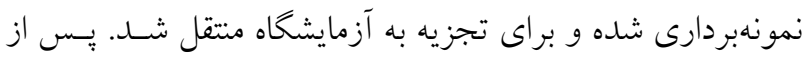

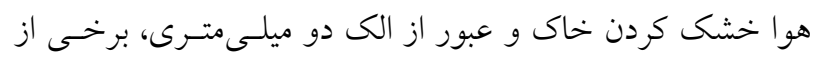

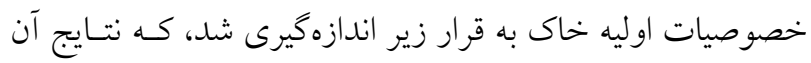

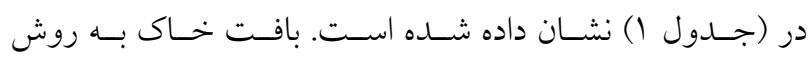
هيدرومترى، فسفر قابل جذب به روش اولسن بـهوسـيله دستَّاه

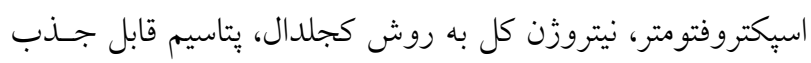

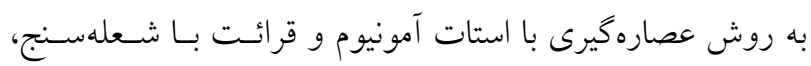
درصد مواد خنثى شونده (آهك) به روش تيتر اسيون با سود، مـاده

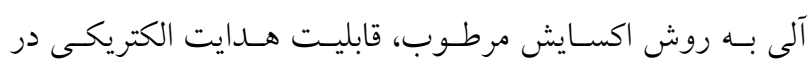

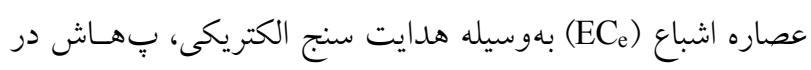

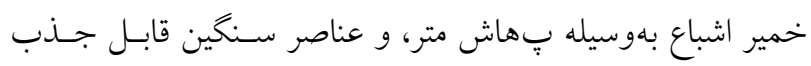

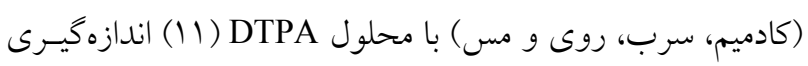




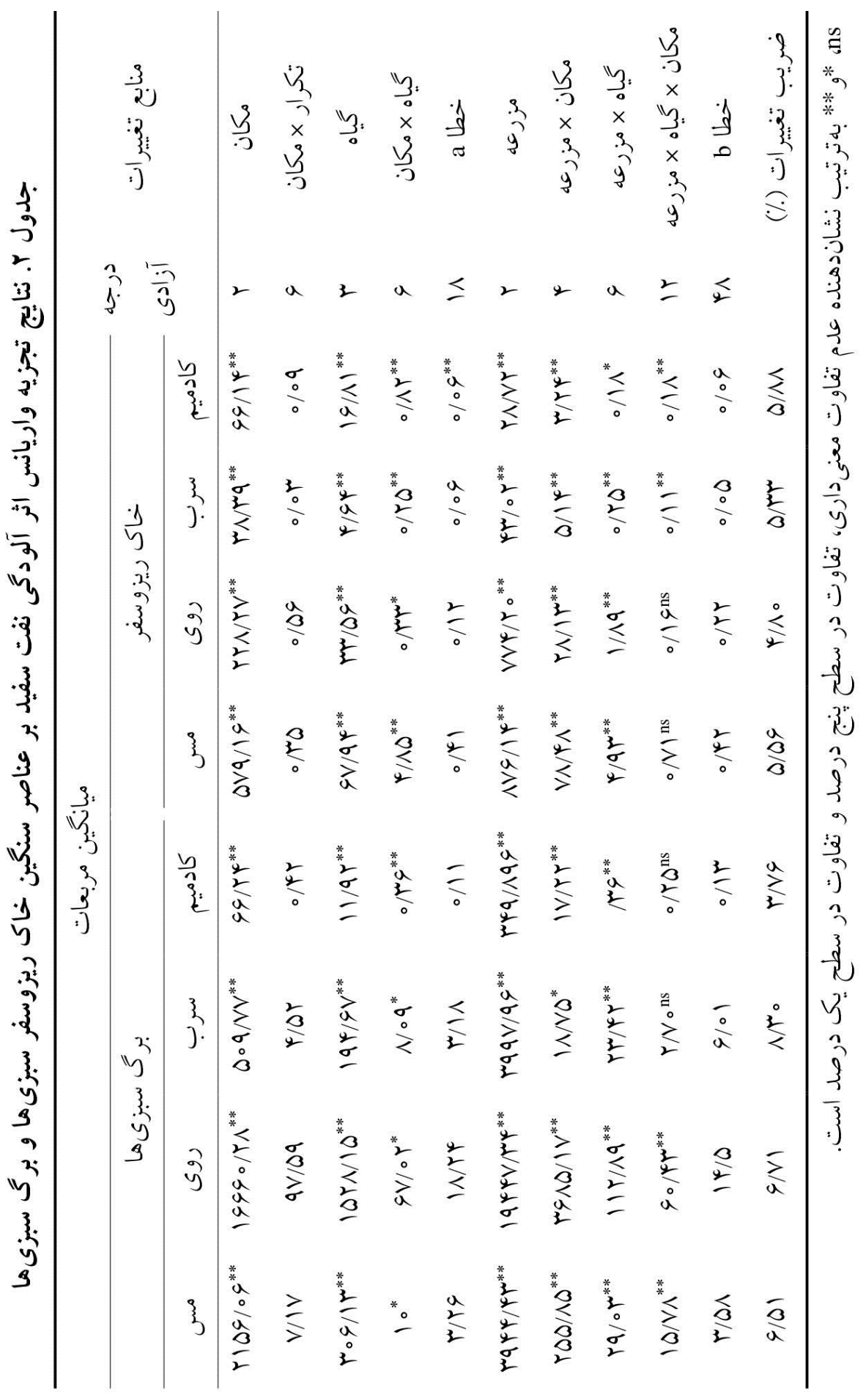



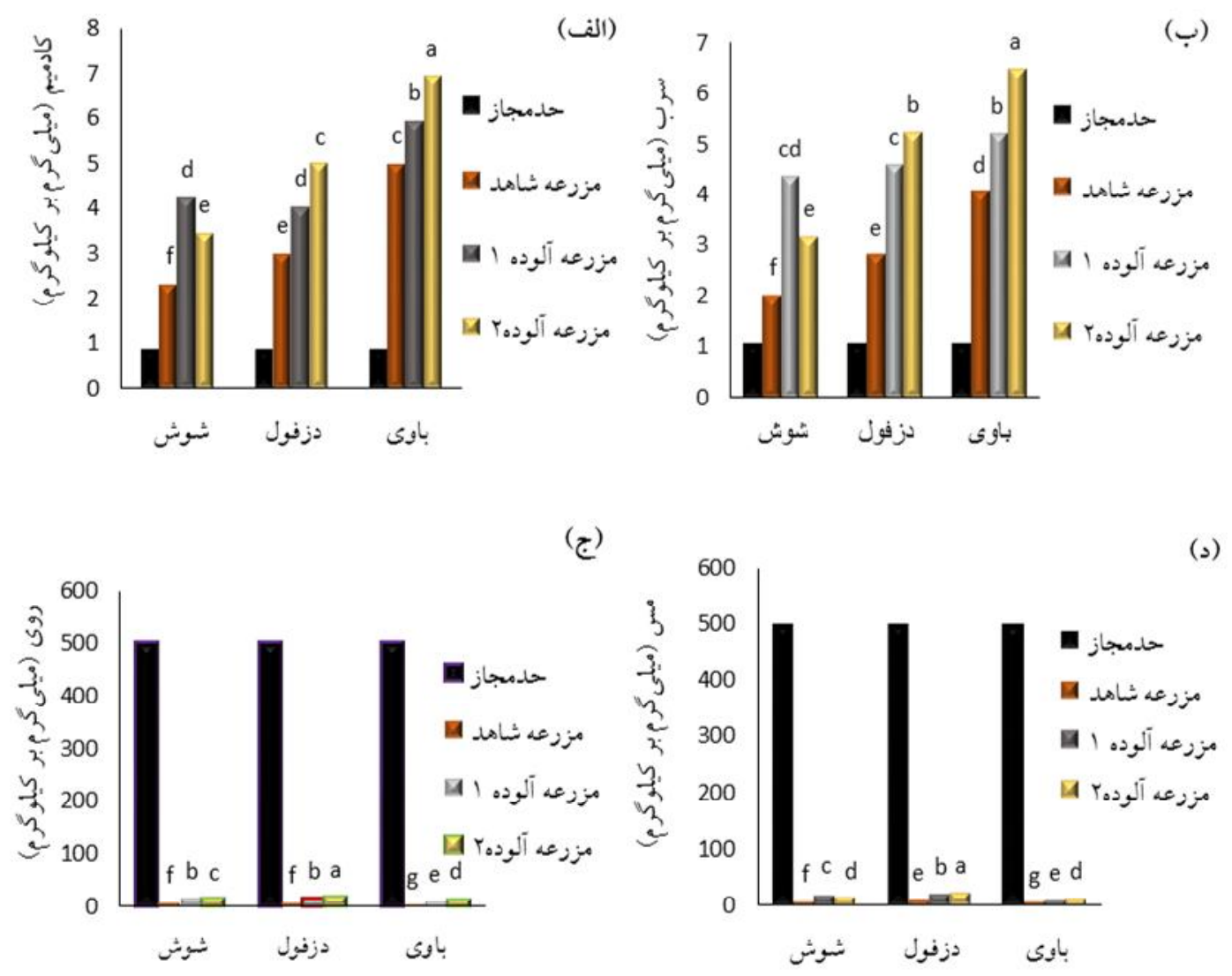

شكل 1. مقايسه ميانكين حد مجاز و غلظت عناصر سنغين قابل جذب ريزوسفر خاك سبزىهاى مختلف در شهرستانهاى مختلف با استفاده

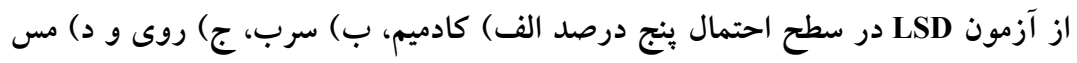

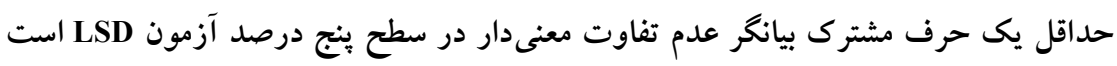

مقدار غلظت عناصر سنگين خــاك ريزوسـفر سـبزىهـا در شهر ستانهاى مختلف

ميانكين ميزان غلظت عناصر سنگين كادميم و سرب نمونههـاى

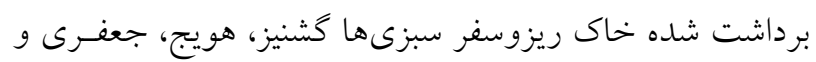
شويد در شهرستان بـاوى نسـبت بـه شهرسـانهـاى دزفـول و

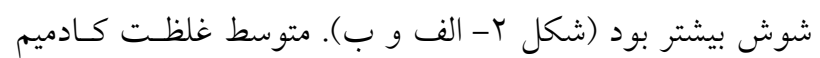

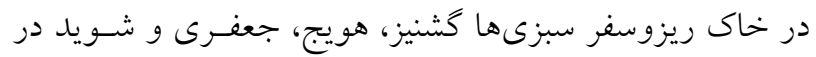

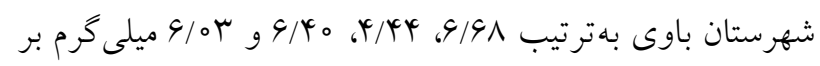

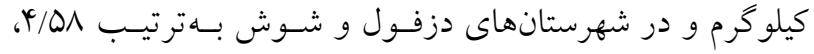
西 كيلو گرم بود (شكل r- الف) كه نشان مىدهد ميـانخين غلظـت
برداشت شده خاك ريزوسفر مزارع آلوده به نفت سـفيد نسـبت به نمونه شاهد بيشتر بود (شكل (1). متوسط غلظت كادميم و سرب خاك ريزوسفر مزارع شـاهد

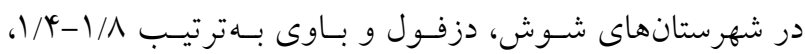

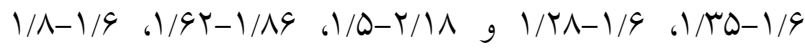
برابر كمتر از مزارع آلوده بود (شكل ا- الـف و ب). همحتنسين

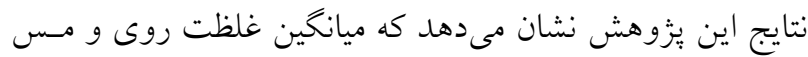

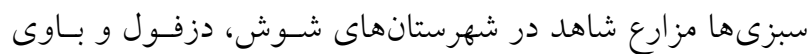
بـــترتب

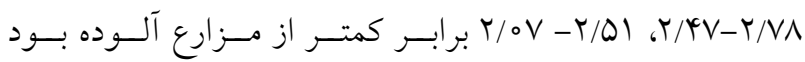

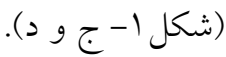



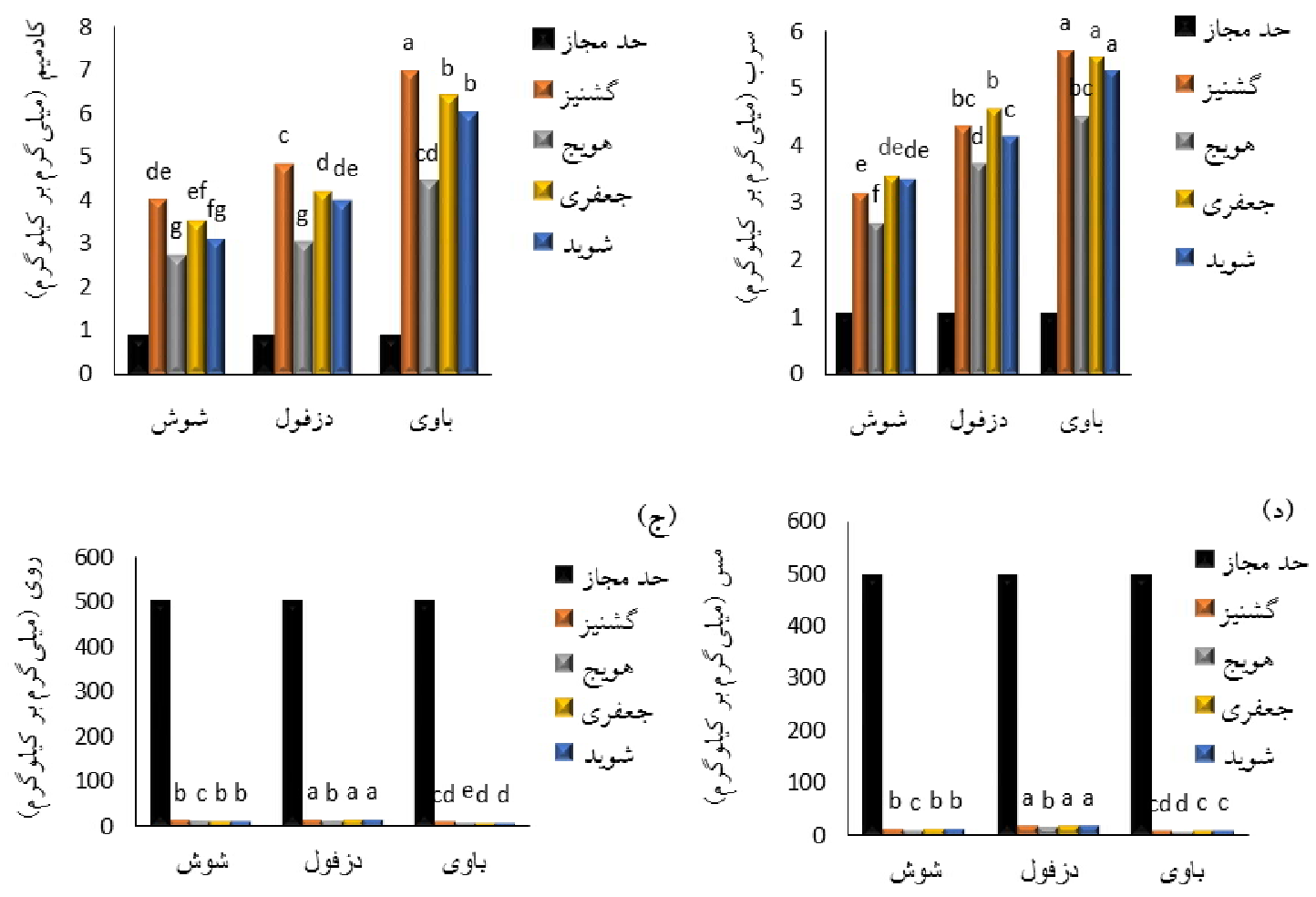

شكل r. مقايسه ميانكين حد مجاز و غلظت عناصر سنگين قابل جذب ريزوسفر خاك سبزىهاى مختلف در شهرستانهاى مختلف با

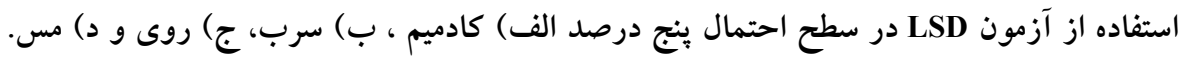

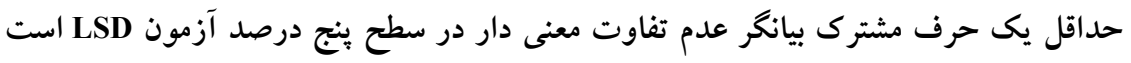

بود (شكل r- ب). كه نشان مسىهــد ميـانخين غلظـت سـرب

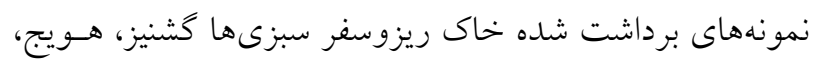

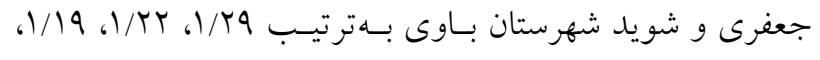
داب 1/TV دزفول و شوش است. غلظت فلز سرب در خاك مزارع شاهد و

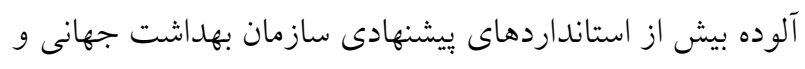
سازمان غذا و كشاورزى سازمان ملل متحد است. براساس نتسايج

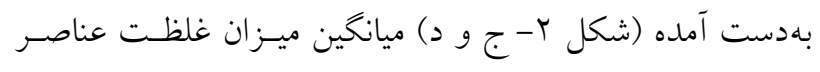
ريز مغذى روى و مس خاك ريزوسفر سبزىهاى گشنيز، هويج،

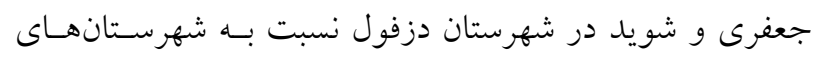

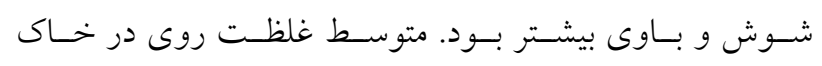

كادميم نمونههاى برداشت شده خاك ريزوسفر سبزىها گشـيز،

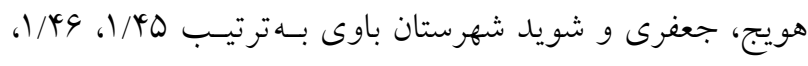

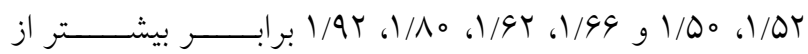
شهرستانهاى دزفول و شـوش اسـت. غلظـت فلـز كـادميوم در

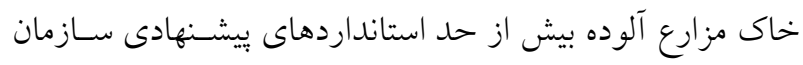
بهداشت جهانى (WHO) و سازمان غذا و كشاورزى سازمان ملل

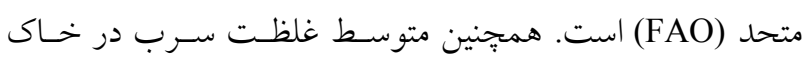

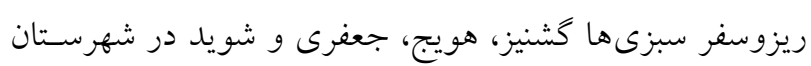

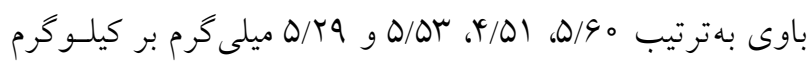

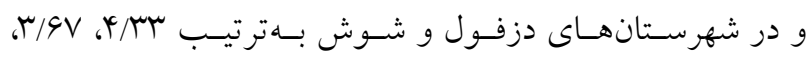
舟 
جدول ب . مقايسه حد مجاز عناصر سنخين در سبزىها و ميزان عناصر سنخين در سبزىها مزارع شاهد و آلوده به نفت سفيد

\begin{tabular}{|c|c|c|c|}
\hline سبزىهاى آلوده به نفت سفيد & سبزىهاى بدون آلودكى نفت سفيد & 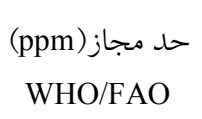 & عناصر سنگين \\
\hline $9-14$ & $V-Q$ & $\circ / Y-\circ / \Lambda$ & كادميم \\
\hline$\mu_{0-} \varphi_{0}$ & $\mid Y-r_{0}$ & $\circ / 1-10$ & سرب \\
\hline$p r-1 \circ 9$ & $r \Psi-T \Delta / \Delta$ & $100-Y \circ 0$ & روى \\
\hline$M T-Y V$ & $1 Y-19 / 0$ & ro & مس \\
\hline
\end{tabular}

سـرب، روى و مـس قابـل جــنب در خــاك شـد. خـاكهـاى آلوده به نفت سفيد نسبت به خاكهاى غير آلـوده حساوى مقـدار بيشترى از فلزات ســخين هسـتند. ايسن بــان معنسى اسـت كـه خاك نخهدارنده فلزات سـنخين موجـود در مـواد نفتسى اسـت،

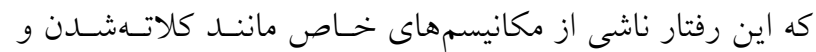
جذب توسط خاك حاصـل مسىشـود. همجنــين خـزارش شـده كـهـ رابطـه بـين اتصـال آلاينـدههــا و سـطوح خـاك بـه علـت نيروى جذب سـطحى اسـت. فلـزات ســخين بـا بـار مثبـت از طريق جذب الكترواستاتيكى جذب سطوح ذرات رس خاى بـا بار منفى مىشوند (با). فلزات سـنخين موجـود در نفـت خـام

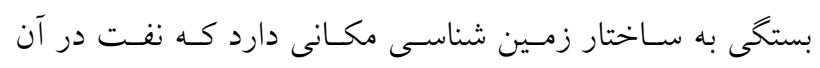
تشكيل مىشود. برخى از فلزات موجود در نفت بـهعنـوان يـك شاخص از فلزت موجود در سـنخ منشـأ اسـت و ايسن فلـزات سنخين ممكن است نقش مهمى بهعنو ان كاتـاليزور تبـديل مـواد

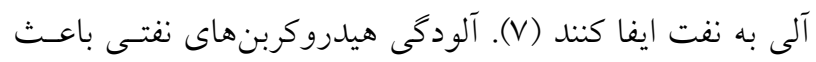
تغييـر خــواص فيزيكسى، ميكروبيولـوزيكى و شـيميايى خــاى مىشود، كه منجر به ساخت عناصر ضرورى (كربن آلى، فسـفر، كلسيم و منيزيم) و غير ضرورى (سرب، روى، آهـن، كبالـت و مس) در خاك و انتقال آنها به بافتهاى گيـاهى مسىشـود. ايسن عو امل بستخى به شـرايط محيطى و نـوع تركيـات محلـول در خاك دارد (1) - (1). طبق حد استاندارد (جدول r) در خاك مزارع آلوده به نفـت

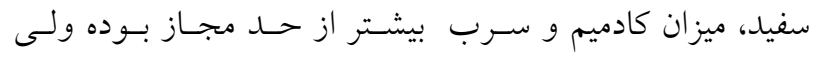
عناصر روى، مس در مزارع كمتر از حد مجـاز بـود. نتـايج ايسن
ريزوسـفر سـبزىهــاى گشــنيز، هــويج، جعفـرى و شـويد در

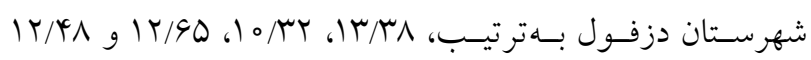
ميلى گرم بر كيلو گرم و در شهرستانهاى شوش و باوى بهترتيب

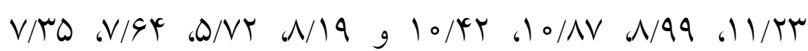

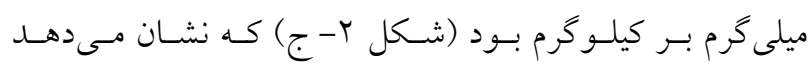
ميانخين غلظت روى نمونههاى برداشت شــه خـاى ريزوسـفر سبزىهاى كشنيز، هـويج، جعفـرى و شـويد شهرسـتان دزفـول

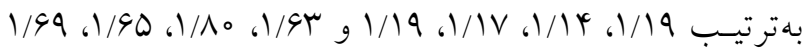
برابر بيشتر از شهرستانهاى شوش و باوى است. متوسط غلظت مس در خاك ريزوسفر سبزىهـاى گشـنيز، هـويج، جعفـرى و

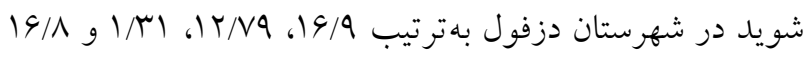
ميلى گرم بر كيلو گرم و در شهرستانهاى شوش و باوى به ترتيب

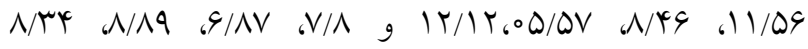
ميلى گرم بر كيلو گرم بود (شكل r- د). كه نشان مىدهد ميانخين غلظت مس نمونههاى برداشت شده خاك ريزوسفر سبزىهـاى كشنيز، هويج، جعفرى و شويد شهرستان دزفول بهترتيب \&4/1/،

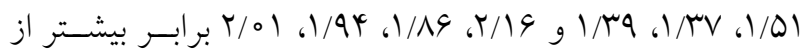
شهرستانهاى شوش و باوى است. امـا غلظـت روى و مـس در خاك هاى مزارع شـاهد و آلـوده در حســ مجـاز اسـتانداردهاى يشينهادى سازمان بهاشت جهانى و سـازمان غـذا و كشـاورزى سازمان ملل متحد است. نفت خـام تركيبسى بيّيجيــده از هـز اران تركيب هيدروكربنى و غير هيدروكربنى از جمله فلزات سـنخين است (Y). نتايج مذكور نشان مسىدهـد اسـتفاده از نفـت سـفيد

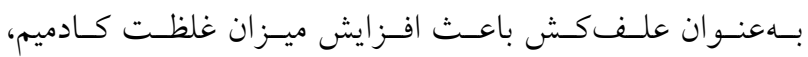


(الف)

(ب)
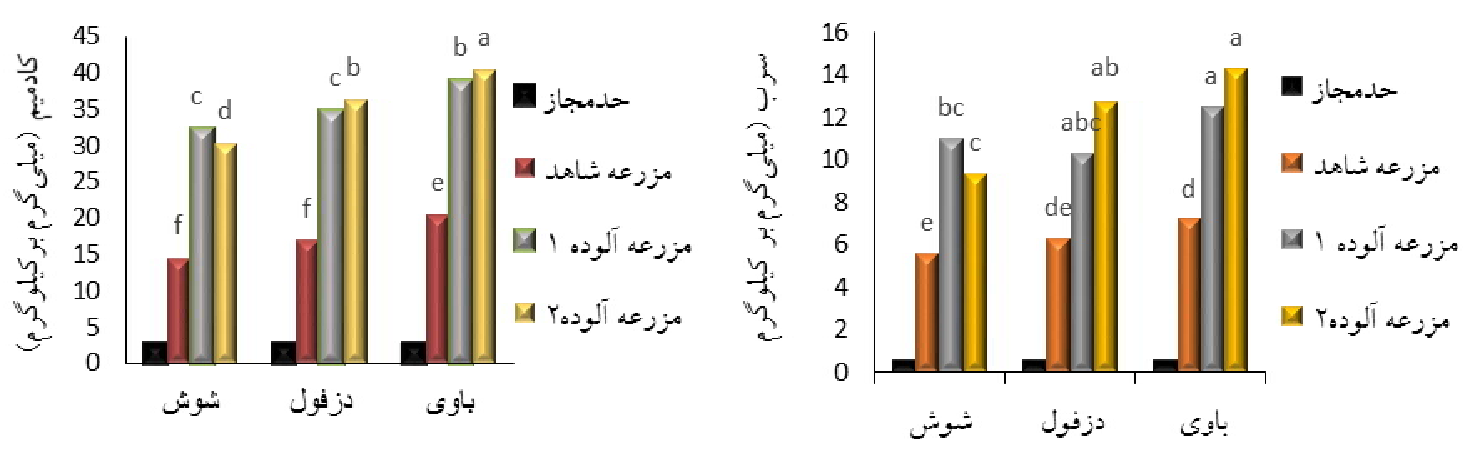

(ج)

(2)
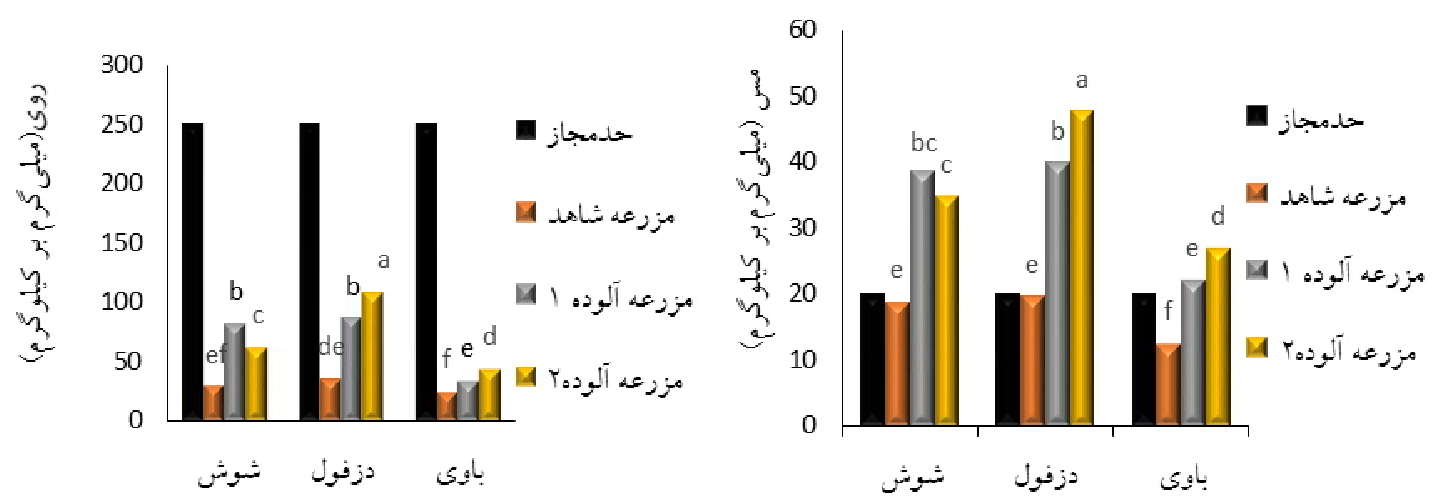

شكل r. مقايسه ميانگين حد مجاز و غلظت عناصر سنگين قابل جذب در سبزىهاى مختلف در شهرستانهاى مختلف با استفاده از

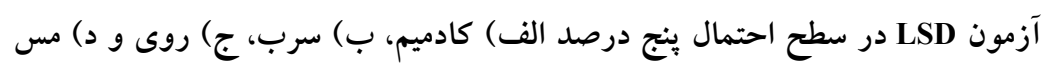

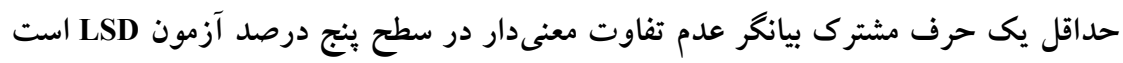

سنخين هستند. در خاى با آلودىى نفتى بهترتيب صـفر، يـى و

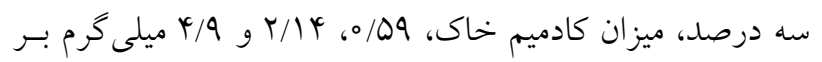

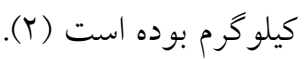

مقدار غلظت عناصر ســخـين سـبزىهـا در شهرسـتانهـاى

مختلف

ميانخين غلظت كادميم، سرب، روى و مس در نمونههـاى كيـاهى

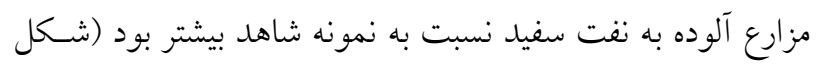

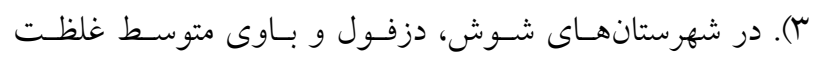

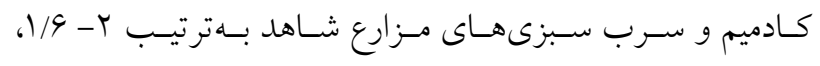

يزّوهش با مطالعه شاميان و همكاران (01) مطابقت نـدارد. آنها

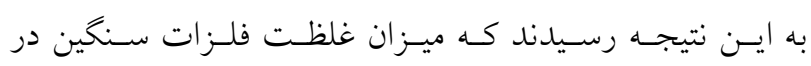

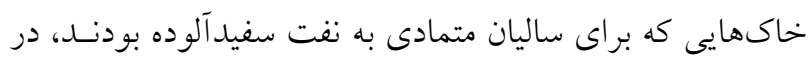

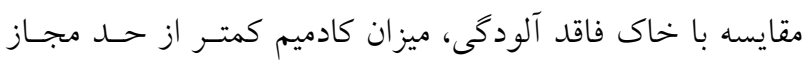

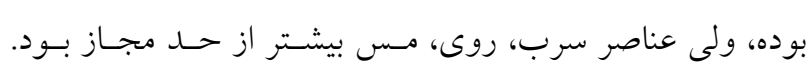

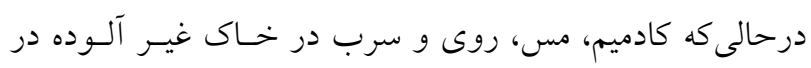
حد مجاز بود. افزايش غلظت فلزات سنخين در خاك آلـوده بــهـ

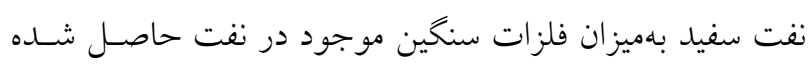

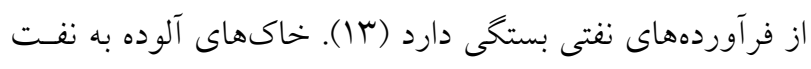

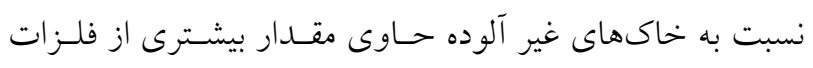


(الف)

(ب)
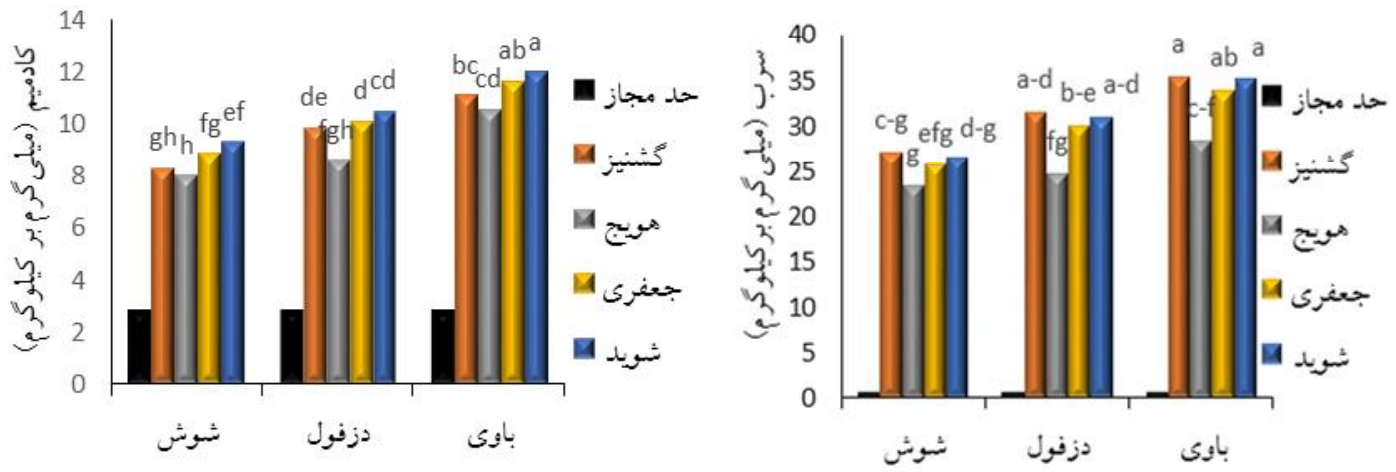

(ج)

(a)
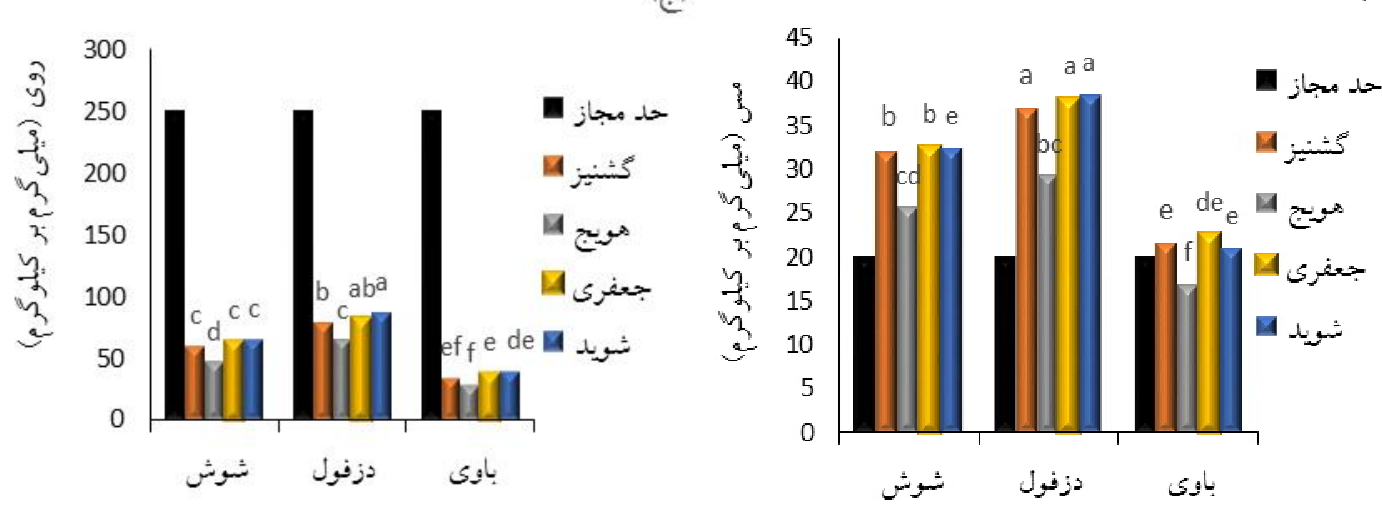

شكل f. مقايسه ميانگين حد مجاز و غلظت عناصر سنگين قابل جذب در سبزىهاى مختلف در شهرستانهاى مختلف با استفاده از آزمون

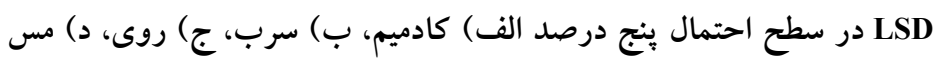
حداقل يك حرف مشتر بيانكر عدم تفاوت معنىدار در سطح ه درصد آزمون LSD است.

شهرستان باوى نسبت به شهرستانهاى دزفـول و شـوش بيشـتر بود (شكل \&). متوسط غلظـت كـادميم در سـبزىهـاى كشـنيز،

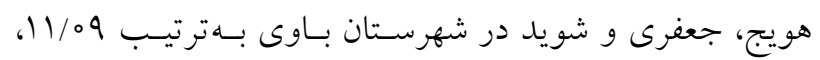

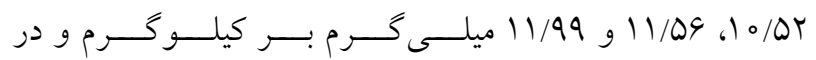

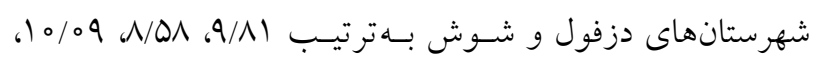
10/KV (شكل بأ- الف). كـهـ نشـان مسىدهــ ميـانخين غلظـت كـادميم نمونههاى برداشت شده سبزىهـاى كُشـيز، هـويج، جعفـرى و

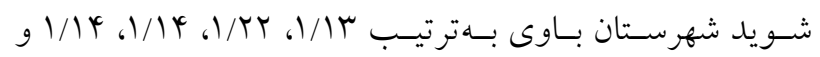

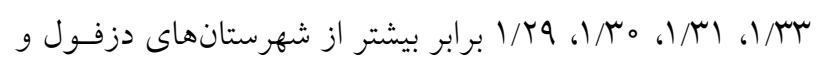
شوش است. همجنـين متوسـط غلظـت سـرب در سـبزىهـاى r- 1/9، 1/9- 1/9 و 1/9 ب ب ابر كمتر از مزارع آلـوده بود (شكل r- الف وب). همخيجنين نتايج بـهدسـت آمـده نشـان مى دهد كه در شهرستانهـاى شـوش، دزفـول و بـاوى ميـانخين

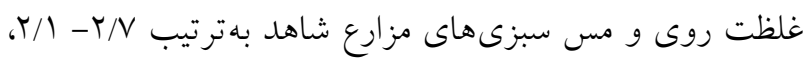
r آلوده بود (شكل س- ج و د). تأثير ميزان نفت سفيد بر مقــدار غلظــت عناصـر ســـين در سبزى ها ميانخين ميزان غلظت عناصر سنخين كادميم و سرب نمونههـاى برداشت شده سبزىهاى كشـنيز، هـويج، جعفــى و شـويد در 
از استانداردهاى بيشنهادى سـازمان بهداشـت جهانى و سـازمان

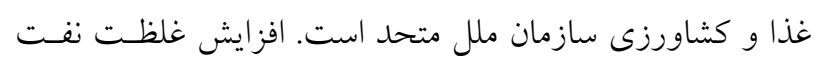

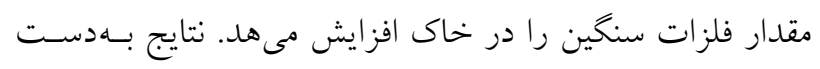

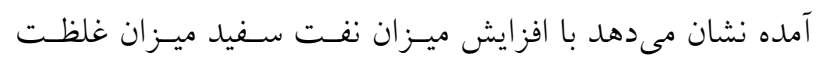

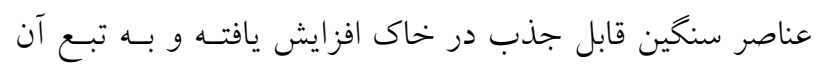

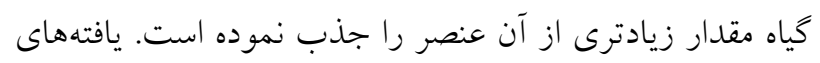

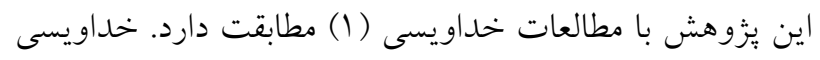

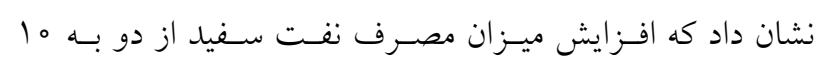

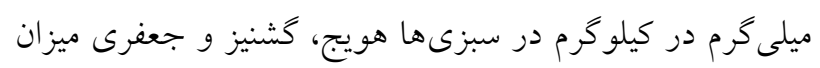

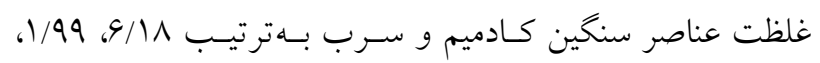

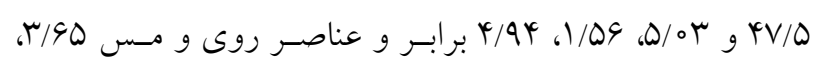

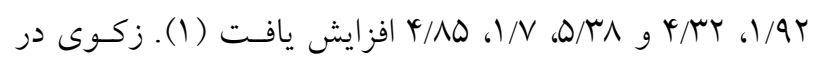

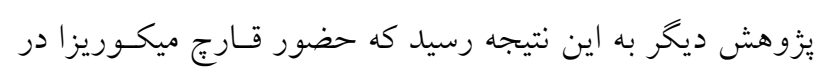

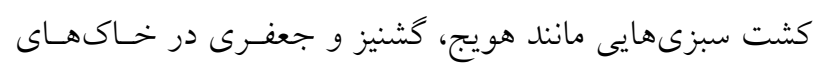

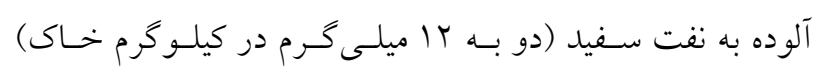

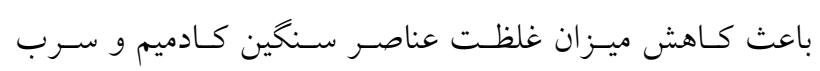
بهترتيب ها

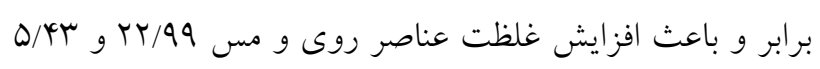

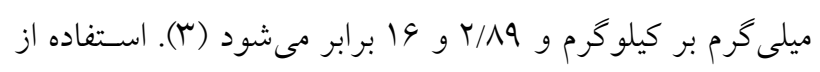

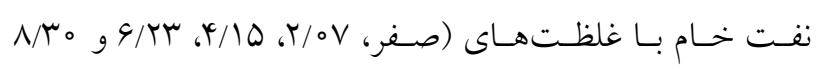

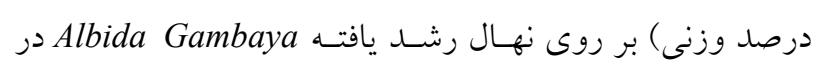

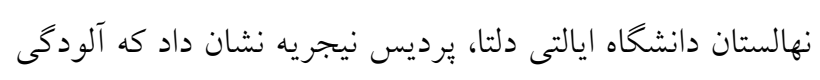

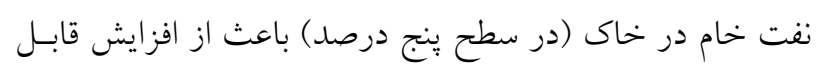

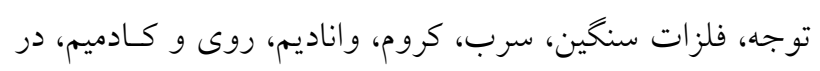

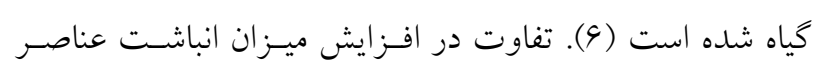

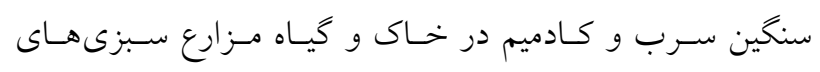

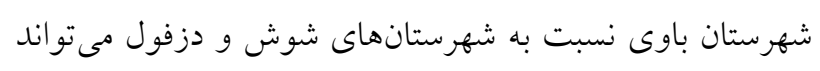

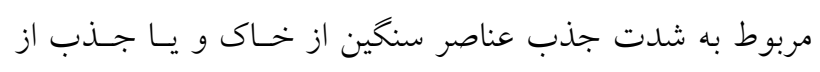

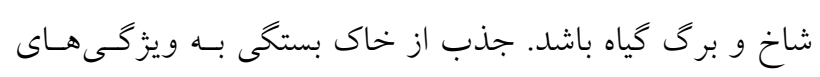

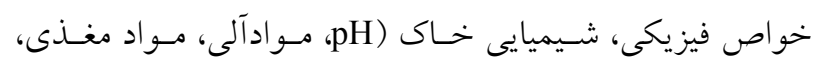

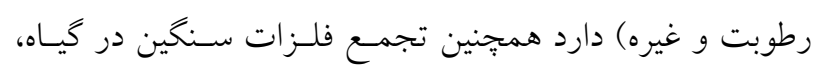

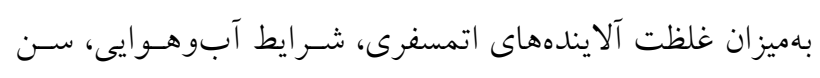

كُشنيز، هويج، جعفرى و شـويد در شهرسـتان بـاوى بـهترتيـب rه/هr

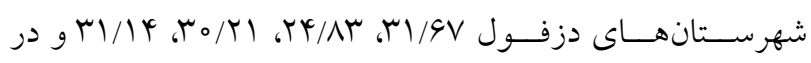

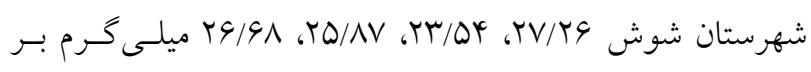

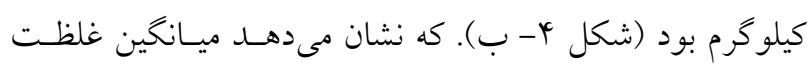

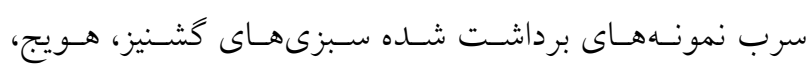

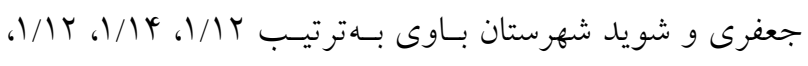

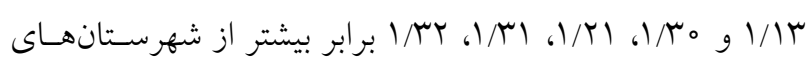
دزفول و شوش است. اين مطلب بهوضسوح در مسورد كـادميم و

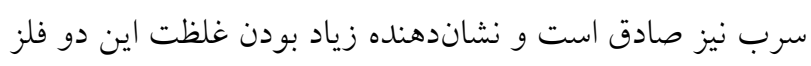

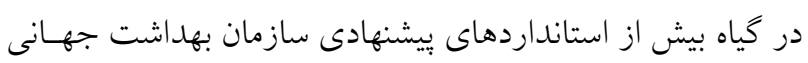

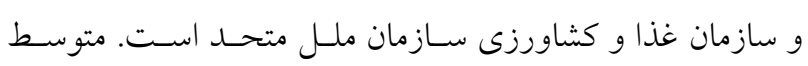

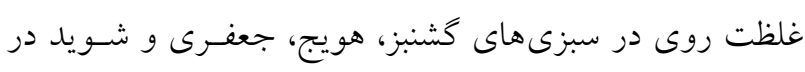

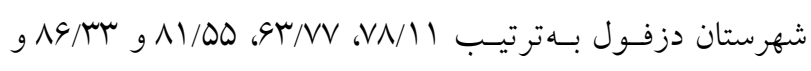
در شهرستان شوش و بـاوى بـهـترتيـب SN/N

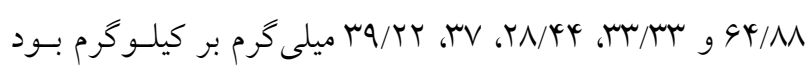

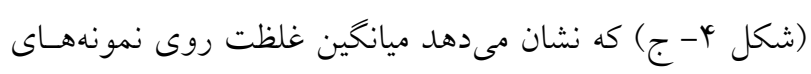

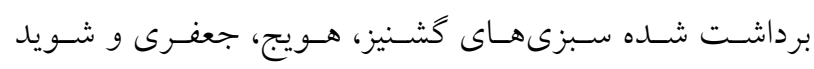

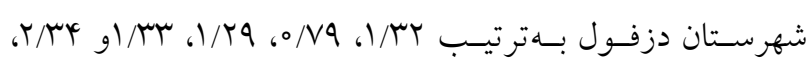

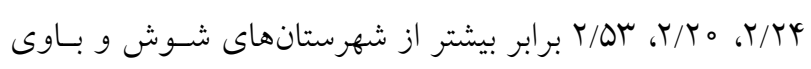

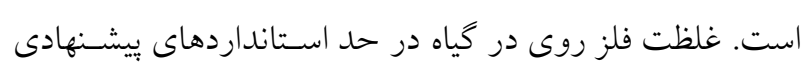

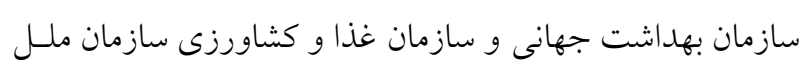
متحد است. متوسط غلظت مس در سبزىهـاى كشــنيز، هـويج، ونسان

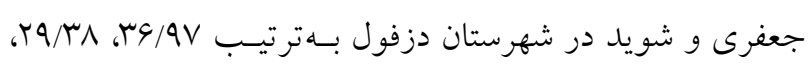

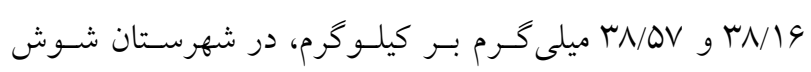
به ترتيب Q

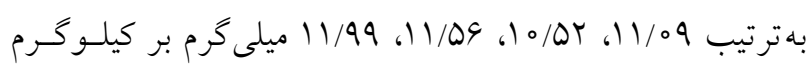

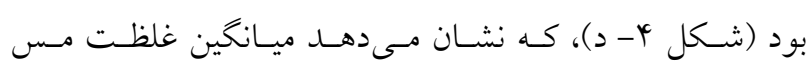

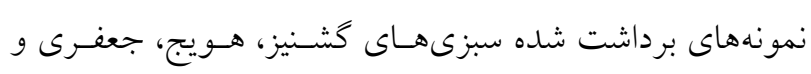

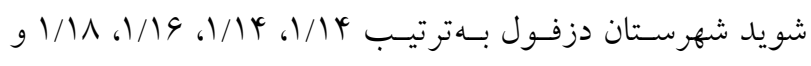

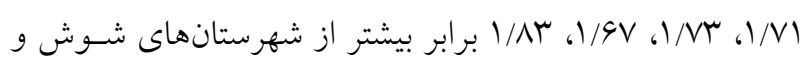

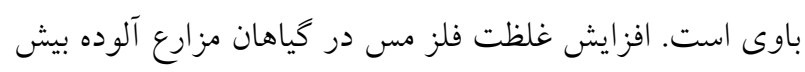


كزارش كردند كه شورى بـر جـــب روى و مس تـأثيرى (IV)

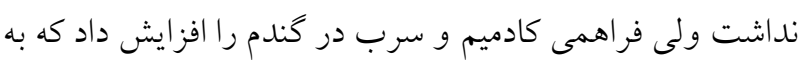

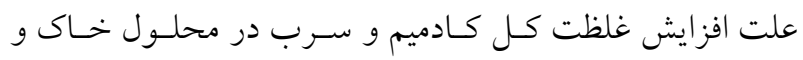

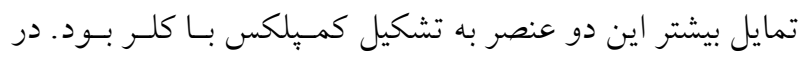

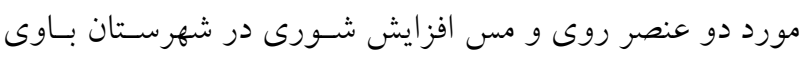

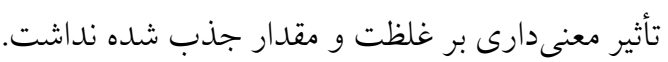

\section{نتيجه گيرى}

بررسى غلظـت عناصـر سـنخين در خـاك ريزوسـفر و بخـش

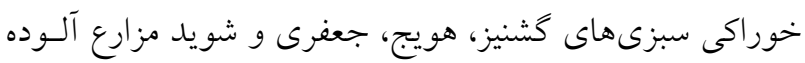
به نفت سفيد در مزارع شهرستانهاى مختلف استـان خوزستستان

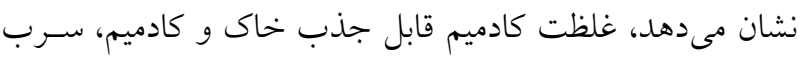
و مس بخش خوراكى سبزىها بيش از حد مجاز اسـت. ميـزان

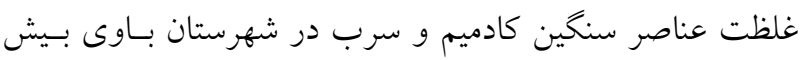

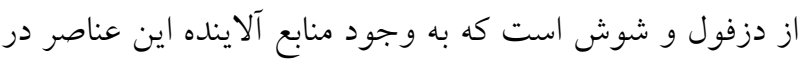

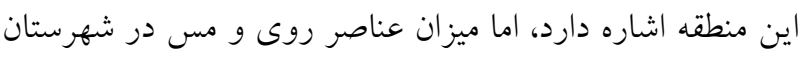

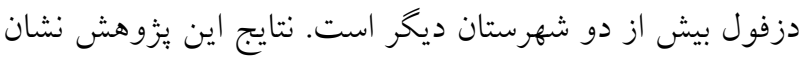

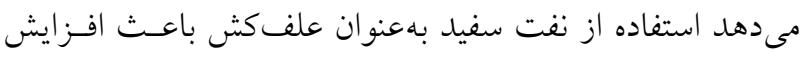

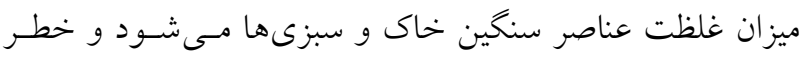

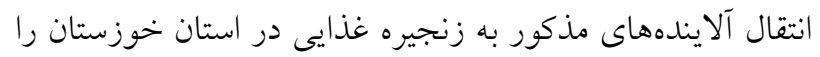

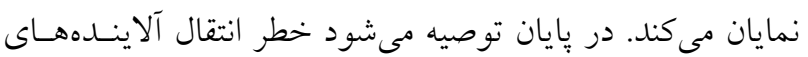

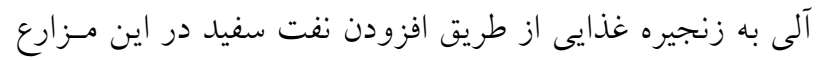

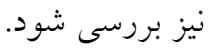

كياه و سطح برى كياه نيز بستخى دارد. زياد بودن شورى خـاك در شهرستان باوى دسترسى زيستى كادميم، در خاكهاى آلـوده به فلزات سنخين را افزايش مى دهد و بر جذب و و تجمع كـادميم

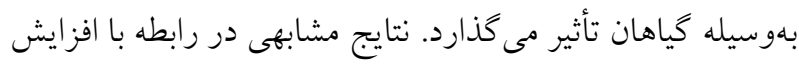

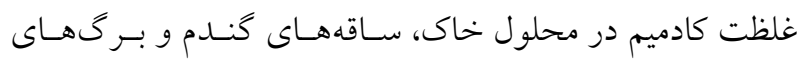
جغنار سويسى و جذب آن با افـزايش غلظـت كلـر در محلـول

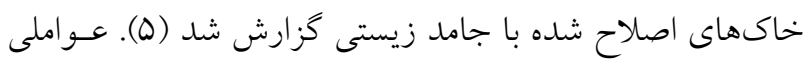

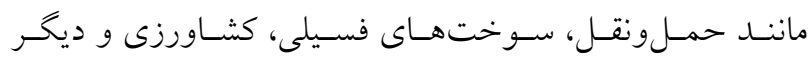

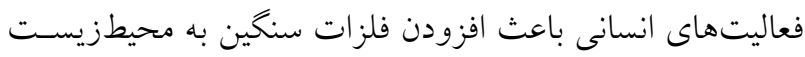

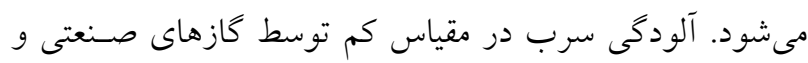

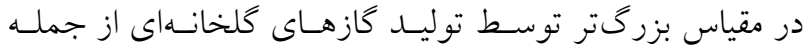
وسايل نقليه موتورى با استفاده از بنزين سربدار ايجاد مى لشود.

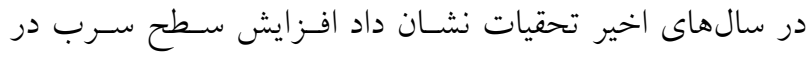
خاك و يوشش كياهى، بهطور قابل توجهى به آلودگى ترافيك با

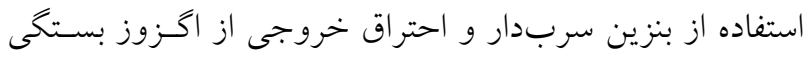

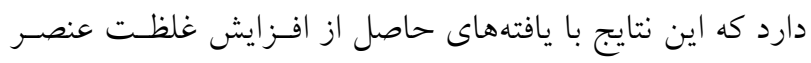

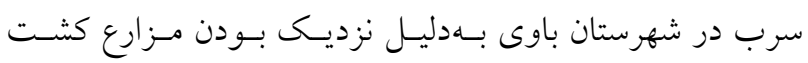

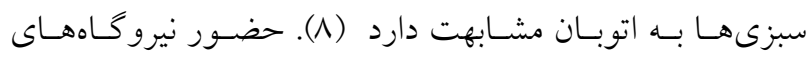

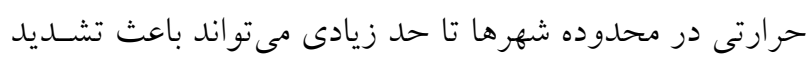

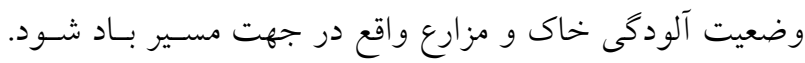

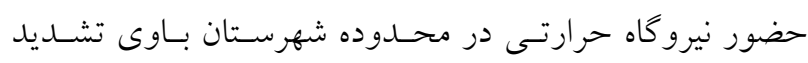

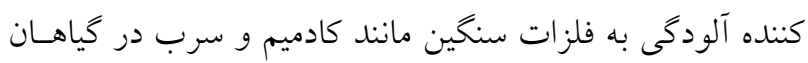

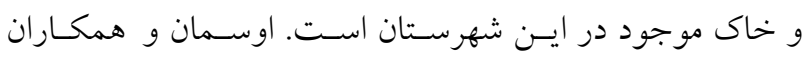

\section{منابع مورد استفاده}

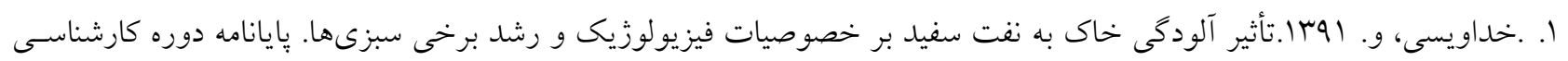
ارشد دانشخاه كشاورزى و منابع طبيعى رامين خوزستان.

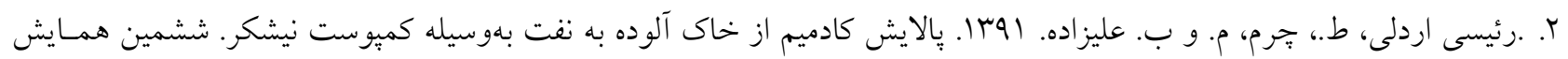

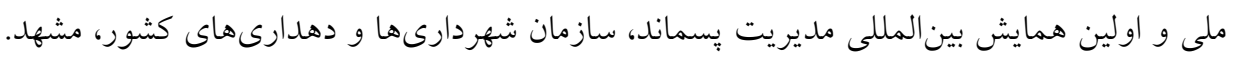

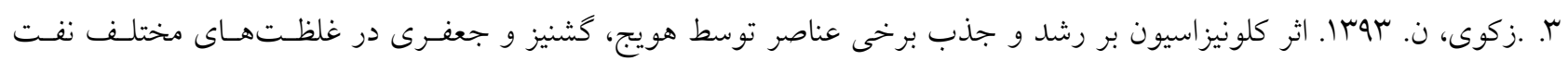

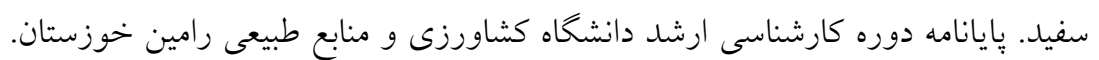

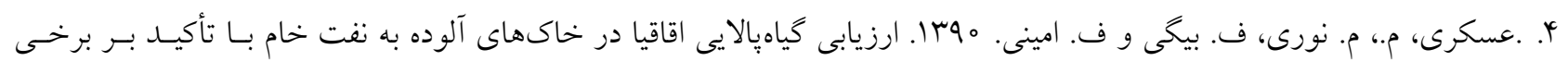




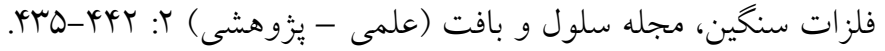

$$
\begin{aligned}
& \text { ه. .فلاحتى مرودست، ع.، ع. حسين يور و س. ح. طباطبايى. rوبا. اثر شورى و لجن فاضلاب بر فراهمسى و جــذب فلـزات سـنخين } \\
& \text { توسط جو، نشريه آب و خاك (علوم و صنايع كشاورزى) TV }
\end{aligned}
$$

6. Agbogidi, O. M. and E. M. Ilondu. 2012. Heavy metal contents of gambaya albida (Linn.) seedlings grown bin soil contaminated with crude oil. J. of bio. and Chem. Res. 29: 320- 325.

7. Akpoveta, O. V., F. Egharevba and O. W. Medjor. 2011. A pilot study on the hydrocarbon and its kinetics on kerosene simulated soil, Int. J. of Environ. Sci. 2: 54-67.

8. Çelik, A., A. A. Kartal, A. Akdoğan and Y. Kaska. 2005. Determining the heavy metal pollution in Denizli (Turkey) by using Robinio pseudo-acacia L. J. Environ. Int. 31: 105- 112.

9. Gilyazov, M. U. and I. A. Gaisin. 2003. The agroecological characteristic and recultivation ways of the petropolluted chernozems of Tatarstan Republic. Phen Press, Kazan.

10. Khillare, P. S., D. S. Jyethi and S. Sarkar. 2012. Health risk assessment of polycyclic aromatic hydrocarbons and heavy metals via dietary intake of vegetables grown in the vicinity of thermal power plants. J. Food and Chem. Toxic. 50: 1642-1652.

11. Lindsay, W. L. and W. A. Norvell. 1978. Development of a DTPA soil test for zinc, iron, manganese, and copper. J. Am. Soil Sci. Soc. 42: 421-428.

12. Newman, L. A. and C. M. Reynolds. 2004. Phytodegradation of organic compounds. Curr. Opin. Biotechnol. 15: $30-225$

13. Okonokhua, B. O., B. Ikhajiagbe, G. O. Anoliefo and T. O. J. Emede. 2007. The effects of spent engine oil on soil properties and growth of maize (Zea mays L.). J. Appl. Sci. Environ. Manage. 11: 147 - 152.

14. Salanitro, J. P. 2001. Bioremediation of PHCs in soil. Adv. Agron. 72: 53-105.

15. Shamiyan, R. K., K. J. I. Nirmal, N. K. Rita and G. P. Jignasha. 2013. An assessment of physicochemical properties, heavy metal enrichment and fungal characterization of refined kerosene impacted soil in an and Gujarat, India. Inter. J. Environ. 2: 174-164.

16. Sharonova, N. and I. Breus. 2012. Tolerance of cultivated and wild plants of different taxonomy to soil contamination by kerosene. J. Sci. of the Total Environ. 424: 121-129.

17. Usman A. R. A., Y. Kuzyakov and L. A. Stahrk. 2005. Effect of immobilizing substances and salinity on heavy metals availability to wheat grown on sewage sludge-contaminated soil. J. Soil and Sediment Contaminat. 14: 329- 344 . 


\title{
The Effects of Kerosene Usage on Heavy Metals Uptake by some Vegetables in Khuzestan Province
}

\author{
Z. Sorkheh and B. Khalilimoghaddam ${ }^{1 *}$
}

(Received: Jan. 17-2016; Accepted: May 15-2017)

\begin{abstract}
The purpose of this research was to study the effects kerosene by a factorial experiment in the nested design in three replications. The factors included region (Shush, Dezful and Bavi), plant (parsley, dill, coriander and carrot), and management practice (control, contaminated field with kerosene 1, contaminated field with kerosene 2). Heavy metals concentration $(\mathrm{Pb}, \mathrm{Zn}, \mathrm{Cu}$ and $\mathrm{Cd})$ was measured in soil (DTPA extraction method) and plants samples. The results indicated that the average values of the heavy metals concentration in both soil and plants samples subjected to kerosene contaminated treatments were greater than those of the control treatment in all of the regions. The Bavi region had the highest $\mathrm{Cd}$ (14.29 in soil; 11.9 in Dill) and $\mathrm{Pb}$ (40.46 in soil; 35.53 in Coriander) and the lowest $\mathrm{Zn}$ (34.75 in soil ; 28.44 in Carrot) and $\mathrm{Cu}(22.30$ in soil; 16.96 in Carrot) concentration values in both soil and plants subjected to kerosene contaminated treatments. Also, the lowest concentration values of $\mathrm{Cd}(9.33$ in soil; 8.01 in $\mathrm{Carrot})$ and $\mathrm{Pb}$ (30.36 in soil; 23.54 in Carrot) and the highest values of $\mathrm{Zn}$ (109.08 in soil; 86.33 in Dill) and $\mathrm{Cu}$ (47.71 in soil; 38.57 in Dill) were recorded in Shush and Dezful regions, respectively. Based on these findings, kerosene usage could lead to a significant increase in the heavy metals $(\mathrm{Cd}, \mathrm{Cu}$ and $\mathrm{Pb})$ uptake, exceeding the critical level for the vegetables. This might increase the transformation risk of the mentioned heavy metals in the food chain
\end{abstract}

Keywords: Kerosene, Heavy metals, Weeds, Vegetables, Khuzestan.

1. Dept. of Soil Sci., Ramin Agric. and Natural Resour. Univ. of Khuzestan, Ahvaz, Iran.

*: Corresponding Author,moghaddam623@yahoo.ie 